Estudios de

lingüística inglesa aplicada

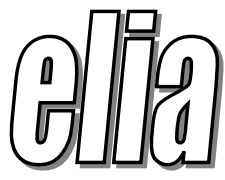

\title{
A CORPUS-BASED STUDY OF ADVERBS OF FREQUENCY IN A GOAL-ORIENTED DISTANCE LEARNING FORUM
}

\section{EL USO DE LOS ADVERBIOS DE FRECUENCIA EN UN FORO VIRTUAL ORIENTADO AL APRENDIZAJE EN LA ENSEÑANZA SUPERIOR A DISTANCIA. ESTUDIO DE CORPUS}

\author{
Jelena Bobkina \\ Universidad Politécnica de Madrid, Spain \\ jelena.bobkina@upm.es
}

\section{Svetlana Stefanova Radoulska}

Universidad Internacional de la Rioja, Spain svetlana.stefanova@unir.net

DOI: http://dx.doi.org/10.12795/elia.2018.i18.02

This paper reports on a corpus-based study that investigated the use of frequency adverbs in students' posts in a goal-oriented virtual forum. The participants in the study were undergraduate students enrolled in two distance learning undergraduate degrees at the International University of la Rioja (Spain), and whose English language level was B1. The forum was part of one of the modules taught within a BEd program with a major in English Language Teaching. The study used a mixed-method approach and the results showed that the erroneous usage of the selected set of adverbs represents $7.47 \%$ of the total number of errors. For the classification of the errors, an error taxonomy was designed, including 9 error types. Findings revealed that the most common error types were those related to the 
position of frequency adverbs in the clause. The paper argues for the unique value of data gathered from virtual forums for the design of preventionoriented teaching material, based on predictable errors.

Keywords: adverbs of frequency, goal-oriented virtual forum, asynchronous computer communication, prevention-oriented teaching material.

El artículo presenta un estudio basado en corpus que investiga el uso de adverbios de frecuencia en las entradas de un foro virtual orientado al aprendizaje. Los participantes del estudio pertenecen a un grupo de alumnos matriculados en dos carreras universitarias impartidas a distancia en la Universidad Internacional de la Rioja (UNIR), todos ellos con nivel de inglés B1. El foro fue una de las tareas asignadas a los alumnos dentro del programa de Mención Enseñanza de la Lengua Inglesa en los grados de Maestro en Infantil y Primaria. El estudio se ha basado en un método de diseño mixto y los resultados demuestran que el uso erróneo de los adverbios fue detectado en el 7,47\% de los casos. Para el análisis de errores y su clasificación, se ha diseñado una taxonomía basada en 9 tipos de errores. Los resultados demuestran que los errores más frecuentes han sido los relacionados con el posicionamiento de los adverbios dentro de la oración. El artículo defiende el valor del corpus recopilado como una base para el diseño de material didáctico orientado a la prevención de errores.

Palabras clave: adverbios de frecuencia, foro virtual orientado al aprendizaje, comunicación virtual asincrónica, material de enseñanza orientado a prevención de errores

\section{Introduction}

Second language acquisition (SLA) research has traditionally favoured experimental, metalinguistic data over the exploration or analysis of corpus data (Granger, 2002, p. 5). While the use of corpora in L1 studies has been a common practice over the last decades (MacWhinney, 2000), less attention has been paid to the studies of corpora in L2 research (Gries, 2015). To give but one example, Tyler (2012) offers a thorough discussion of many experimental results, while very few corpus studies are included.

ELIA 18, 2018, pp. 15-49

DOI: http://dx.doi.org/10.12795/elia.2018.i18.02 
Despite this initial neglect, this trend has changed in recent years as more researchers are becoming increasingly interested in "extensive naturalistic data to understand L2 grammar acquisition and development" (Lozano \& Mendikoetxea, 2013, p. 68). As Leech rightly points out, information about frequency is "one benefit that corpora can provide and that cannot be provided by other means", which is why "there is a need for a re-appraisal of the links between frequency, corpora and language learning" (2011, p. 7). The information from L2 production can help us gain a better grasp of the linguistic system developed by L2 learners, uncovering linguistic patterns that point to underlying factors in SLA (Ädel, 2015; Callies, 2015; Granger, 2012). Not surprisingly, learner corpus research (LCR) has become a fast-expanding field of second language research, with corpus data as "a major source of data in S/FLA research, both on their own and in combination with experimental data" (Gries, 2015, p. 159). Corpus studies are becoming increasingly relevant to the research of SLA, complementing findings from experimental and classroom studies, and trying to provide answers to questions related to language learning (Gablasova, Brezina, \& McEnery, 2017; Gardner \& Davies, 2007; Granger, Gilquin, \& Meunier, 2015; Rakhilina et al., 2016).

Still a young field of research, learner corpus research has undergone significant development in terms of medium and text types, research design, and individual variability. Thus, with respect to medium and text types, the dominant focus in LCR has traditionally been on writing, in particular, essay writing, though a growing number of projects focus on learner speech (Granger, Gilquin, \& Meunier, 2015), and online multimodal communication (Lin, 2015). This last type is becoming especially attractive for researchers as it creates new interactional patterns where traditional distinctions between oral and written discourse are constantly blurred (Sindoni, 2013). To address the application of corpora in language teaching and learning in Spain, we should also take into account Díez-Bedmar's overview of the main research topics of seven written Computer Learner Corpora (CLC) by Spanish students of English. She argues that despite the growing number of learner corpora compiled in Spain, "the overall picture of Spanish students' written command in English is somehow patchy and difficult to visualise" (2009, p. 921). Her statement is still valid for presentday corpus-based research, which fails to reflect the complexity of the overall picture and account for the use of English as a foreign language in virtual learning environments (VLE). The fast development of VLE in 
tertiary education means that topic-related discussion forums have become an essential medium of interaction between students, hence they need special critical attention.

\section{Theoretical Background}

\subsection{Corpora in Grammar Studies and Language Education}

The question of how to teach grammar to EFL/ESL learners has long been one of the most controversial issues in SLA (Ellis, 2006). In fact, the way grammar is taught to English language learners has evolved considerably over decades of experience from teaching grammar limited to instruction on discrete points isolated from meaning to focusing on communication through conversational practices, listening comprehension activities, and the use of authentic texts.

In the final decades of the $20^{\text {th }}$ century, important developments took place in the field of grammar teaching. First, researchers in cognitive philology and SLA highlighted the fact that attention to certain linguistic forms is crucial for language learning (DeKeyser, 2007; Ellis, Busturkmen, \& Loewen, 2002; Schmit, 2001). In fact, according to Schmidt (2001), a conscious apprehension and awareness of a language form is necessary for its further processing. As a result, new approaches to grammar pedagogy, such as teaching grammar in context (Celce-Murcia, 1991) or designing grammatical consciousness-raising activities (Ellis, 1993; Rutherford, 1987), came to life. Students began to develop an understanding of the way writers' linguistic decisions, such as choice of sentence types, have a real impact on the effect of their texts (Barton, 1999; Hewings \& Hewings, 2005).

At the same time, computer-assisted studies made it possible to conduct research of unprecedented scope and complexity, changing radically the way in which grammar research was performed (Conrad, 2000). To start with, corpus-based research can provide valuable information to help teachers and textbook writers with their decision about sequencing of material, type context, and natural discourse. Questions like: what are the most common grammar forms, what structures best exemplify natural language discourse, or what are the most frequently used words with certain grammar structures, can hardly be answered without the help of corpus-based analyses.

ELIA 18, 2018, pp. 15-49

DOI: http://dx.doi.org/10.12795/elia.2018.118.02 
This greatly amplified scope of research offered new opportunities for teachers and students to explore different grammar aspects of a language. Corpus benefits in terms of students' language proficiency have actually been proven by a number of scholars (Garner, 2013; Meunier, 2007, 2010; Varley, 2008). Numerous studies have pointed to its usefulness, and in particular, for error correction in EFL/ESL writing (Bernardini 2004; Chambers 2005; Gaskell \& Cobb, 2004; Gray, 2005; Neff et al., 2001). Information about frequencies, word associations, and analysis of register differences drawn from corpus research can help material developers and teachers to increase the meaningful input provided to learners (Biber \& Conrad, 2004; Gries, 2015).

Moreover, corpus-based research has claimed to have a "vindicating" role in the field of Error Analysis (EA), providing it with high-precision tools for error evaluation judgements and reviving it as a discipline known as Corpus-based error analysis (Castillejos López, 2009; Dotti \& O'Donnell, 2014; Jichun, 2015; Pérez Sánchez, 2013; Shichun, 2004; Torrado Cespón \& Díaz Lage, 2017). The analysis of students' errors offers valuable information about the way and the amount of language learned by a student, as well as the characteristics of the learner internal constructs, known as interlanguage (Selinker, 1972, 1992). Thus, EA becomes crucial to understanding SLA processes and elaborating efficient language pedagogy.

The analysis of learners' errors is also essential for the design of language teaching methods in terms of material and natural discourse (Jichun, 2015). Besides, the EFL learners' mother tongue can be taken into consideration to create suitable pedagogies and materials, as it greatly influences the process of acquiring skills in particular areas of English grammar. This contrasts to the fact that most of the material for ELT is designed to be applicable to students coming from different language backgrounds (Castillejos López, 2009; O’Donnell, 2012).

When describing learner language, interlanguage fossilizatiton is frequently referred to as one of the most common characteristics of SLA (Han, 2004; Wei, 2008). Selinker (1972, p. 229) defines it as a mechanism that underlines surface linguistic material which speakers tend to keep in their productive performance in spite of the learners' positive ability, opportunity, and motivation to learn and acculturate into the target society. In addition, a number of scholars (Bongaerts, 1999; Ioup, 1994; Nikolov, 
2009) consider that complete success among adult students is rare or almost impossible, and should be described in terms of general failure. The most common fossilization errors are those related to "negative transfer" or "interference", a language phenomenon that explains how language learners make errors by borrowing certain patterns form their first language (Amara, 2015; Brown, 2001; Horwithz, 2008; Parker, 1994).

Extensive research dealing with language interference errors has been done by corpus linguists both to identify the most common problems among Spanish learners of English and to provide some corrective feedback (Alejo González, 2010; Castillejos López, 2009; Coe, 1987; Crandall, Dias, Gingras, \& Harris, 1981; Mendikoetxea, Murcia Bielsa \& Rollinson, 2010; Pérez Sánchez, 2013; Stefanova \& Bobkina, 2015). Studies show that grammar errors are the most common ones at all levels (Alonso Alonso, 1997; Pérez Sánchez, 2013), being personal and relative pronouns, prepositions, determiners, verb tenses, word order, and false cognates, to mention but a few, the most problematic areas for Spanish-speaking learners of English.

One problematic grammar issue that has not been thoroughly investigated by corpus linguists is the placement of adverbs. The position of adverbs in the sentence is fundamental and may result in changing the meaning of sentences and making it grammatically incorrect (CelceMurcia \& Larsen-Freeman, 1999; Raimes, 2001). Although adverbs are used by EFL learners with a high frequency, even the most advanced users of English have difficulty in using them correctly (Lei, 2012; Yimaz \& Dikilitaş, 2017). It means that high proficiency in English does not guarantee the accurate use of adverbs.

Despite a number of studies (Leech, Rayson, \& Wilson, 2001; Odlin, 2001; Parrot, 2000; Solís Hernández, 2006; confirming that misplaced adverbs can be a troublesome issue for many learners, not much research taking authentic learner data into account has been carried out. Although adverb placement plays a central role in sentence formation, adverbs are often considered to be a kind of "dustbin" wordclass (Crystal, 1995). According to some researchers, the "neglect of adverbs in linguistic studies is palpable" (Philip, 2008, p. 1301) and often leads to overgeneralisation.

ELIA 18, 2018, pp. 15-49～DOI: http://dx.doi.org/10.12795/elia.2018.118.02 


\subsection{Corpora and Text-based Asynchronous Computer Communication}

Though most of the studies in Learner Corpus still focus on written language, there is an increasing number of works on spoken language and on online computer communication (Harvey, 2012; Lin, 2015; Sasaki, 2010). This last type of communication is becoming especially attractive for researchers as it reflects the change in the "conventional opposition between oral-primitive and written modern cultures" (Sindoni, 2013, p. 20).

Multimodal forms of communication brought by new technologies are taking new dimensions, modifying traditional language modes. Thus, according to Martinec \& Van Leeuwen (2008), the new media differs from traditional language in three different ways: 1) they are multimodal as they are made up of different semiotic resources 2) they are non-linear as they combine spatial and temporal patterns, and 3) they are new as they do not adjust traditional language concepts.

The ubiquity of technology has undoubtedly influenced the way we communicate, bringing us to "the age of new orality that [is] highly dependent on writing and literate culture" (Sindoni, 2013, p. 21). Online forums and chats, blogging, social networking websites and media sharing communities require new descriptive models and theories. Not surprisingly, studies in recent years have shown an explosion of interest in investigating the language used in the electronic communication (DeJonge \& Kemp, 2012; Lyddy, Farina, Hanney, Farrell, \& O’Neill, 2014; Varnhagen, McFall, Pugh, Routledge, Sumida-MacDonald, \& Kwong, 2010).

In the same way, there is a growing amount of studies on electronic communication in the area of EFL/ESL studies, as it provides learners with authentic input and opportunities to participate in the target social and cultural contexts (Ackerley, 2013; Belz \& Vyatkina, 2005; Dooly \& O’Dowd, 2012; Liaw \& Master, 2010; Lin, 2013). It is particularly true for asynchronous computer-mediated type of communication (CMC), such as virtual forums and blogs, as they are not restricted to real-time interaction, and therefore allow learners to be more careful with their contributions (Montero, Watts, \& Garcia-Carbonell, 2007). Besides, created in textbased form, they are easily transmitted, stored, achieved, re-evaluated, and edited.

ELIA 18, 2018, pp. 15-49～DOI: http://dx.doi.org/10.12795/elia.2018.i18.02 
It is necessary to note that the unique nature of online forums has been recognised by a number of research studies that have analysed different language features of EFL/ESL students' forums: vocabulary (Sasaki, 2010), grammar (Sauro, 2009), reading skills (Leiva de Izquierdo \& Esteves Reyes, 2009); writing skills (Liang, 2010), and have identified a wide range of linguistic features distinctive of learner language in CMC settings. As a consequence of this tendency, computer online communication is moving "back towards speech-like forms and become[ing] mere transcription of speech again" (Kress, 2003, p. 61).

Against this background and the existing gaps in the research into the use adverbs of frequency by EFL undergraduate students in computer online communication and the growing need to connect learner corpus data to material design and classroom methodology, our study aims at analysing adverb-related errors produced in the course of a goal-oriented online discussion of Spanish undergraduate students and discussing the practical application of our findings for the design of prevention-oriented pedagogical material that can help students avoid predictable errors. The main research questions are the following:

RQ1: What are the most frequent errors in the use of adverbs of frequency in the contributions of Spanish undergraduate students to a goal-oriented online forum?

RQ2: Can data from online discussion forums be used as a source of prevention-oriented pedagogical material for a particular VLE?

By pursuing these research questions, our study aims to address the need for a more direct connection between the interpretation of results of learner corpus-based studies and EFL teaching material design.

\section{Methodology}

\subsection{Study Background and Participants}

The participants in the present study were undergraduate students enrolled in two fully distance learning programs at the International University of la Rioja (Spain), namely Preschool Education Bachelor's

ELIA 18, 2018, pp. 15-49 DOI: http://dx.doi.org/10.12795/elia.2018.i18.02 
Degree and Primary Education Bachelor's Degree. Both degrees offer an Expert in English Language Teaching program, which includes a number of modules aimed at training ESL/EFL teachers. The program includes English Grammar, English Morphology, Syntax, and Semantics, English Phonetics, Advanced Didactics of the English Language, and ICT Tools Applied to the Learning of English Language. Students can take one or several modules at a time, adapting the number of modules to their individual situation. The Expert in English Language Teaching program requires an initial B1 level of language proficiency (Council of Europe, 2001), which is mentioned in the study path information. All students are Spanish speakers of English as a Foreign Language (EFL). One of the assignments in each module consisted in contributing to a virtual forum on a pre-established topic related to the course content. Professors set up a discussion forum, posting an initial question, and participants were encouraged to contribute at any time over three weeks. Students were required to interact with their classmates, sharing their experiences and ideas on the topic.

The present study analysed the learner corpus data gathered from the posts of 666 students to two goal-oriented online discussion forums, part of the module ICT Tools Applied to the Learning of English Language. The learner corpus was compiled with data by students enrolled in Preschool Education Bachelor's Degree over the period of three academic years 2013-2016 and in Primary Education Bachelor's Degree over the period of five academic years 2011-2016.

\subsection{Data Collection and Material}

We adopted a mixed-method approach, which implies a plurality of "theoretical assumptions, methodological traditions, data gathering and analysis techniques, and personalized understandings and value commitments" (Green, 2007, p. 13). In the first phase, the corpus was compiled by the professors in charge of the course. The process consisted of the following steps: 1) downloading all the contributions and saving them in .txt format, applying a specific coding protocol, 2) registering all the information in an excel file, 3) distinguishing between different contributions made by the same student to the same forum, and 4) eliminating the names of the students from the corpus (Castillo Rodríguez

ELIA 18, 2018, pp. 15-49 DOI: http://dx.doi.org/10.12795/elia.2018.i18.02 
\& Díaz Lage, 2015, pp. 198-200. For further details about the information registered in the excel file, see Figure 1 below).

To ensure the representativeness of the samples, the professors in charge of the course established a coding protocol. The documents containing students' contributions to the virtual forum were downloaded and saved in .txt format. In Preschool Education Bachelor's Degreethe module is called ICT Tools Applied to the Learning of English Language (ICT) and in Primary Education Bachelor's Degree - Tecnologías de la información aplicadas al aprendizaje de la lengua inglesa (TIC). Two goal-oriented virtual forums were created and coded A and B, respectively. Thus, 02TOENICTA stands for Student 2, Texto original, English, ICT Tools to the Learning of English language, Forum A (Castillo Rodríguez \& Díaz Lage, 2015). Figure 1 shows how the corpus compilation information was stored.

\begin{tabular}{|c|c|c|c|c|c|c|c|}
\hline Código & $\begin{array}{l}\text { Alumno }-\mathrm{N} .{ }^{\circ} \\
\text { registro }\end{array}$ & $\begin{array}{l}\text { N. }{ }^{\circ} \text { de } \\
\text { contribuciones }\end{array}$ & Titulación & Asignatura & $\begin{array}{l}\text { Curso } \\
\text { académico }\end{array}$ & Per y cuatrimestre & Palabras TO \\
\hline 01TOENICTA & Alumno 1 & 2 & $\begin{array}{l}\text { Grado de Maestro en } \\
\text { Educación Infantil }\end{array}$ & $\begin{array}{l}\text { ICT tools applied to the learning of } \\
\text { English language }\end{array}$ & $2014-2015$ & Per52 1Q & 291 \\
\hline 02TOENICTA & Alumno 2 & 2 & $\begin{array}{l}\text { Grado de Maestro en } \\
\text { Educación Infantil }\end{array}$ & $\begin{array}{l}\text { ICT tools applied to the learning of } \\
\text { English language }\end{array}$ & 2014-2015 & Per52 1Q & 416 \\
\hline 02TOENICTB & Alumno 2 & 3 & $\begin{array}{l}\text { Grado de Maestro en } \\
\text { Educación Infantil }\end{array}$ & $\begin{array}{l}\text { ICT tools applied to the learning of } \\
\text { English language }\end{array}$ & $2014-2015$ & Per52 1Q & 621 \\
\hline 03TOENICTA & Alumno 3 & 5 & $\begin{array}{l}\text { Grado de Maestro en } \\
\text { Educación Infantil }\end{array}$ & $\begin{array}{l}\text { ICT tools applied to the learning of } \\
\text { English language }\end{array}$ & $2014-2015$ & Per52 1Q & 596 \\
\hline O4TOENICTA & Alumno 4 & 2 & $\begin{array}{l}\text { Grado de Maestro en } \\
\text { Educación Infantil }\end{array}$ & $\begin{array}{l}\text { ICT tools applied to the learning of } \\
\text { English language }\end{array}$ & $2014-2015$ & Per52 1Q & 186 \\
\hline O4TOENICTB & Alumno 4 & 2 & $\begin{array}{l}\text { Grado de Maestro en } \\
\text { Educación Infantil }\end{array}$ & $\begin{array}{l}\text { ICT tools applied to the learning of } \\
\text { English language }\end{array}$ & $2014-2015$ & Per52 1Q & 135 \\
\hline
\end{tabular}

Figure 1. Corpus compilation information

In the second phase, a sequential quantitative and qualitative study was conducted. In order to process the data collected from the learner corpus, identify the frequency of use of a set of adverbs, and detect various categories of errors, we used the concordance software AntConc Tools 3.2.4 (see Figure 2). This was followed by a qualitative analysis of the concordance lines containing errors. 


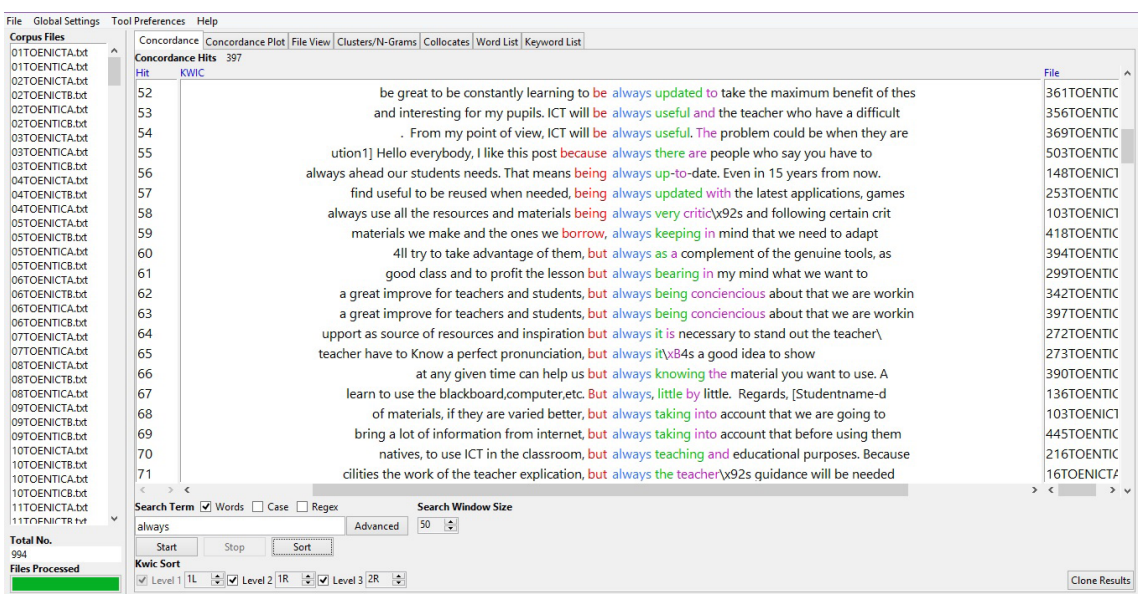

Figure 2. Search results for the adverb always in a KWIC (KeyWord in Context) format

To classify the results obtained with the corpus management software AntConc by error types and to establish error patterns, a special errorcoding protocol was designed and followed (see Section 4 below).

The corpus ENTECOR consists of two sub-corpora: TICOR and TRAINCOR. The present study examines TICOR, which includes all the contributions to a virtual forum over a period of five academic years, from 2011/2012 to 2015/2016. The sub-corpus is composed of two elements: Component 1 - Learner Corpus Preschool Education Bachelor's Degree, compiled over three academic years (2013-2014 to 2015-2016) and Component 2 - Learner Corpus Primary Education Bachelor's Degree, compiled over five academic years (2011-2012 to 2015-2016) (see Table 1). 


\begin{tabular}{|c|c|c|c|}
\hline Type of corpus & $\begin{array}{c}\text { Number } \\
\text { of } \\
\text { students }\end{array}$ & $\begin{array}{c}\text { Number of .txt } \\
\text { documents }\end{array}$ & $\begin{array}{c}\text { Academic years } \\
\text { of compilation } \\
\text { of the corpus }\end{array}$ \\
\hline $\begin{array}{c}\text { Component 1: Learner } \\
\text { Corpus Preschool Education } \\
\text { Bachelor's Degree }\end{array}$ & 155 & 231 & $\begin{array}{l}2013-2014 \\
2014-2015 \\
2015-2016\end{array}$ \\
\hline Component 2: Learner & 511 & 763 & $2011-2012$ \\
Corpus Primary Education & & & $2012-2013$ \\
Bachelor's Degree & & & $2013-2014$ \\
& & & $2014-2015$ \\
\hline TICOR: Component 1+ & 666 & 994 & \\
Component 2 & & & \\
\hline
\end{tabular}

Table 1. Learner corpus

The difference between the academic years of compilation of the two components is due to the fact that the module ICT Tools Applied to the Learning of English Language was included in the Primary Education Bachelor's Degree program in 2011-2012 and in the Preschool Education Bachelor's Degree program two years later. In both degrees, the module is taught in English.

As shown in Table 2, the total corpus amounts to 424,801 words: Component 1 includes 107,042 words and Component 2 includes 317,759 words.

\begin{tabular}{|c|c|c|}
\hline Learner corpus & Word tokens & Word types \\
\hline $\begin{array}{c}\text { Component 1 } \\
\text { Learner Corpus Preschool Education } \\
\text { Bachelor's Degree }\end{array}$ & 107,042 & 4,816 \\
\hline $\begin{array}{c}\text { Component 2 } \\
\text { Learner Corpus Primary Education Bachelor's } \\
\text { Degree }\end{array}$ & 317,759 & 9,320 \\
\hline $\begin{array}{c}\text { TICOR } \\
\text { Component 1 + Component 2 }\end{array}$ & 424,801 & 10,440 \\
\hline
\end{tabular}

Table 2. Descriptive Data of Learner Corpus 
The corpus is monolingual, written, open, electronic, synchronic, complete, and untagged, and displays the following features:

- Quality: the conditions of the collection of the language data do not influence in any way the production of the students' contributions and all the texts in the learner corpus are actual examples of undergraduate non-academic written production.

- Quantity: the size of the corpus $(424,801$ word tokens) and the number of participants (666 students) allow us to draw conclusions on the errors in the use of adverbs of frequency by a specific group of undergraduate students.

- Representativeness: the quality of the corpus ensures the status of the corpus as a representative sample of the written non-academic production of the participants in the study.

- Retrievability: data and related documentation are stored in electronic format and retrievable when required.

- Documentation: full information of the text is stored and can be used for further research.

\section{Analysis and Results}

Our analysis of the corpus was concerned with the use of the following adverbs of frequency: always, constantly, ever, frequently, generally, never, normally, occasionally, often, rarely, regularly, repeatedly, seldom, sometimes, usually. The main criterion for choosing these particular adverbs was the participants' level of language proficiency, which ranges between $\mathrm{B} 1$ and B2, as the Expert in English Language Teaching program requires a B1 level of language proficiency. Thus, the study focused on those adverbs, classified as common for A1 to B2 EFL users in the Cambridge Dictionary Online (2018). Adverbs such as continually and scarcely were excluded from the study, for they are classified as C1-C2 level (Cambridge Dictionary Online, 2018) and errors related to them were not considered representative for the establishment of patterns of deviation

ELIA 18, 2018, pp. 15-49 DOI: http://dx.doi.org/10.12795/elia.2018.i18.02 
from the prescriptive rules for the design of prevention-oriented teaching material.

In what follows, we present the results of adverb occurrence in descending order of frequency and the corresponding total number of mistakes in the corpus. Adverbs are ranked in terms of their position, determined by the frequency of use.

\begin{tabular}{|c|c|c|c|}
\hline Adverbs & Rank & Frequency of use & Number of errors \\
\hline always & 167 & 397 & 43 \\
\hline sometimes & 168 & 394 & 20 \\
\hline never & 373 & 136 & 9 \\
\hline usually & 416 & 122 & 2 \\
\hline often & 442 & 112 & 8 \\
\hline normally & 919 & 38 & 3 \\
\hline constantly & 927 & 37 & 6 \\
\hline ever & 942 & 36 & 2 \\
\hline frequently & 1486 & 17 & 3 \\
\hline generally & 1488 & 17 & 0 \\
\hline rarely & 1952 & 11 & 3 \\
\hline regularly & 3106 & 5 & 0 \\
\hline occasionally & 3461 & 4 & 0 \\
\hline repeatedly & 0 & 0 & 0 \\
\hline seldom & 0 & 0 & 0 \\
\hline Total & 15847 & 1326 & 99 \\
\hline
\end{tabular}

Table 3. Results ordered in terms of frequency of use of the selected adverbs 
The results show that the adverbs of frequency included in the study were used 1326 times, out of which 99 were erroneous use. The errors represent $7.47 \%$ of the total number of adverbs examined.

For the error detection and analysis, we designed an error taxonomy, based on the surface structure taxonomy (Dulay, Burt \& Krashen, 1982) and assigned a code to each type of error (see Table 4). Dulay, Burt and Krashen (1982) propose four types of error taxonomy: linguistic category, surface structure, comparative taxonomy, and communicative effect taxonomy. We opted for the surface structure taxonomy, because its fourth category, "misordering", is particularly useful for the adequate description of placement-related errors of adverbs of frequency.

The classification of types of errors was informed by the grammar rules for the correct use of adverbs of frequency in Thomson and Martinet's A Practical English Grammar (1986) and Hewings's Advanced Grammar in Use (2005). In it, we employ the terms "simple tenses" and "compound tenses" as used by Thomson and Martinet in the work mentioned above.

As shown in the Table 4, an error taxonomy of adverb placement and other adverb-related errors can be described as a set of 9 error types.

\begin{tabular}{|c|c|c|c|}
\hline $\begin{array}{c}\text { Error } \\
\text { Code }\end{array}$ & Deviation from the rule & $\begin{array}{c}\text { Description of the } \\
\text { error type }\end{array}$ & $\begin{array}{c}\text { Number of } \\
\text { occurrences }\end{array}$ \\
\hline EC1 & ADV + TO BE & $\begin{array}{c}\text { Adverb is placed } \\
\text { before the verb to } \\
\text { be }\end{array}$ & 22 \\
\hline EC2 & $\mathrm{V}+$ ADV (simple tenses) & $\begin{array}{c}\text { Adverb is placed } \\
\text { after the simple } \\
\text { tenses of other } \\
\text { verbs }\end{array}$ & 21 \\
\hline EC3 & Main V + ADV (compound & $\begin{array}{c}\text { Adverb is placed } \\
\text { tenses) } \\
\text { with compound } \\
\text { tenses }\end{array}$ & 25 \\
\hline
\end{tabular}




\begin{tabular}{|c|c|c|c|}
\hline $\begin{array}{l}\text { Error } \\
\text { Code }\end{array}$ & Deviation from the rule & $\begin{array}{c}\text { Description of the } \\
\text { error type }\end{array}$ & $\begin{array}{l}\text { Number of } \\
\text { occurrences }\end{array}$ \\
\hline $\mathrm{EC} 4$ & Have to + ADV & $\begin{array}{l}\text { Adverb is placed } \\
\text { after Used to/Have } \\
\text { to }\end{array}$ & 3 \\
\hline $\mathrm{EC} 5$ & $\begin{array}{c}\text { ADV + STRESSED } \\
\text { AUXILARY (compound verb } \\
\text { form) }\end{array}$ & $\begin{array}{l}\text { Adverb is placed } \\
\text { before the auxiliary } \\
\text { in a compound } \\
\text { verb form when the } \\
\text { auxiliary is stressed }\end{array}$ & 0 \\
\hline EC6 & ALWAYS in initial position & $\begin{array}{l}\text { Always is put at the } \\
\text { beginning of the } \\
\text { sentence }\end{array}$ & 5 \\
\hline EC7 & $\begin{array}{c}\text { SELDOM/RARELY/ } \\
\text { HARDLY EVER/SCARCELY } \\
+ \text { Subject + Operator }\end{array}$ & $\begin{array}{l}\text { Never, seldom, } \\
\text { rarely, hardly ever } \\
\text { - are fronted and } \\
\text { not followed by } \\
\text { Subject-operator } \\
\text { inversion }\end{array}$ & 3 \\
\hline EC8 & $\begin{array}{c}\text { SELDOM/RARELY/ } \\
\text { HARDLY EVER/SCARCELY } \\
+ \text { negative verb forms }\end{array}$ & $\begin{array}{c}\text { Never, rarely, } \\
\text { seldom are used } \\
\text { with negative verb } \\
\text { forms }\end{array}$ & 4 \\
\hline EC9 & Other cases & & 16 \\
\hline
\end{tabular}

$\mathrm{EC} 1, \mathrm{EC} 2$, and $\mathrm{EC} 3$ represent deviations from the major placement rules described in the grammar books mentioned above. EC4 is limited to the use of adverbs of frequency with the semi-modal verb used to and the lexical auxiliary verb have to. EC6 deals with the placement of the adverb always, while EC7 and EC8 stand for deviations of the use of the adverbs of frequency with negative meaning. As expected, EC1, EC2, and EC3 were the most common, representing $68.7 \%$ of the overall erroneous use of adverbs, witha rather homogeneous distribution between the three categories: $22.2 \%$ for EC1, 21.2\% for EC2, and $25.2 \%$ for EC3.

ELIA 18, 2018, pp. 15-49ＯDOI: http://dx.doi.org/10.12795/elia.2018.i18.02 
As can be seen from the examples below, the use of adverbs of frequency with the verb to be (EC1) is still a tricky point for many students (22.2\% of the overall mistakes), presumably due to the fact that the placementof adverbs in Spanish is much more flexible, allowing an adverb to be situated both before after the verb to $b e$.

(1). The material made by one same always is more useful ...

(2).... But we always are interested in ...

(3).... I agree with you X (name of the student), never it's too late to learn something.

(4). ... but the genuine materials always are the best ...

(5). ... are a world of options to do, and usually are very interesting for children...

This becomes evident if we compare the following example of concordance line containing a placement-related error to the variants of its correspondence in Spanish (always = siempre):

(4).... but the genuine materials always are the best ...

(4a). Los materiales auténticos son siempre los mejores.

(4b). Los materiales auténticos siempre son los mejores.

Adverb placement with simple tenses of verbs was identified as another common type of mistake with $21.2 \%$ of the overall cases. This type of erroneous use is particularly persistent with the adverbs always, often, and sometimes.

(6).... and we laugh always when this happens ...

(7). ... because often people abuse them too ...

(8).... and teachers need sometimes work together and those tools would be...

Adverb placement with compound tenses was identified as the most common type of error with $25 \%$ of the overall cases. The study revealed that together with perfect and continuous tenses, modal and passive structures cause considerable difficulties for students, as in examples 11, 13, and 14 below:

(9). We are running out of time always, so where is the need ...

(10). I have seen frequently how some families of my students.

ELIA 18, 2018, pp. 15-49～DOI: http://dx.doi.org/10.12795/elia.2018.118.02 
(11). ... agree with $\mathrm{X}$ (name of the student) about the mistakes that sometimes are found on Internet resources.

(12). ... I have been never teacher, ...

(13).... and we must improve and recycling constantly.

(14). ... and we always must act thinking ...

Another problematic area detected by researchers is the placement of the adverb always in initial position (EC6) (about 5\% of the overall mistakes), as this adverb is rarely used in English at the beginning of a sentence or clause except in imperatives. The examples below show that Spanish undergraduate students tend to place this adverb at the beginning of the sentence, following the collocation pattern characteristic of the Spanish language.

(15). Always, I can remember this famous dialogue ...

(16). ... and always we try to use the most important tools ...

(17). Always we study the grammar ...

Compare:

(17a). Siempre estudiamos la gramática.

(17b). Estudiamos siempre la gramática.

Finally, the negative adverb never and the semi-negative adverb of frequency rarely (Chalker \& Weiner, 1998, p. 356) display two main problems (EC7 and EC8 with $7.1 \%$ of the overall mistakes). The first one is the so-called "double negative", i.e. when a sentence has either "more than one negative word" or "it contains not plus one or more negative words" (Cowan, 2008, p. 98, italics in original). Most double negatives used by the students were of the second type, i.e. they used negative adverbs with negative verb forms, as illustrated by the following examples:

(18).... it won't never happen.

(19). ... lot of teachers who don't use never a PDI or a computer ...

(20). ... to emphasise the fact that teacher will not never be substituted by ICT.

(21). ... that teacher won't never be replaced by ICT.

Additionally, the need for subject-auxiliary inversion when the adverb with negative or semi-negative meaning is fronted in the sentence was often ignored.

ELIA 18, 2018, pp. 15-49～DOI: http://dx.doi.org/10.12795/elia.2018.i18.02 
(22). Rarely, we watched a video.

(23). Rarely we went to another classroom to watch ...

(24). Rarely they are sufficient, except in cases of ...

The overall distribution of the errors identified by the researches in the use of the examined adverbs of frequency are presented in Figure 3. It shows that the widest range of errors can be found in the use of the adverb always (6 types of error), followed by sometimes (4 types of error), constantly, often, and never (3 types of error), and ever, normally and frequently ( 2 types of error). On the other hand, the adverbs usually and rarely display only one type of error.

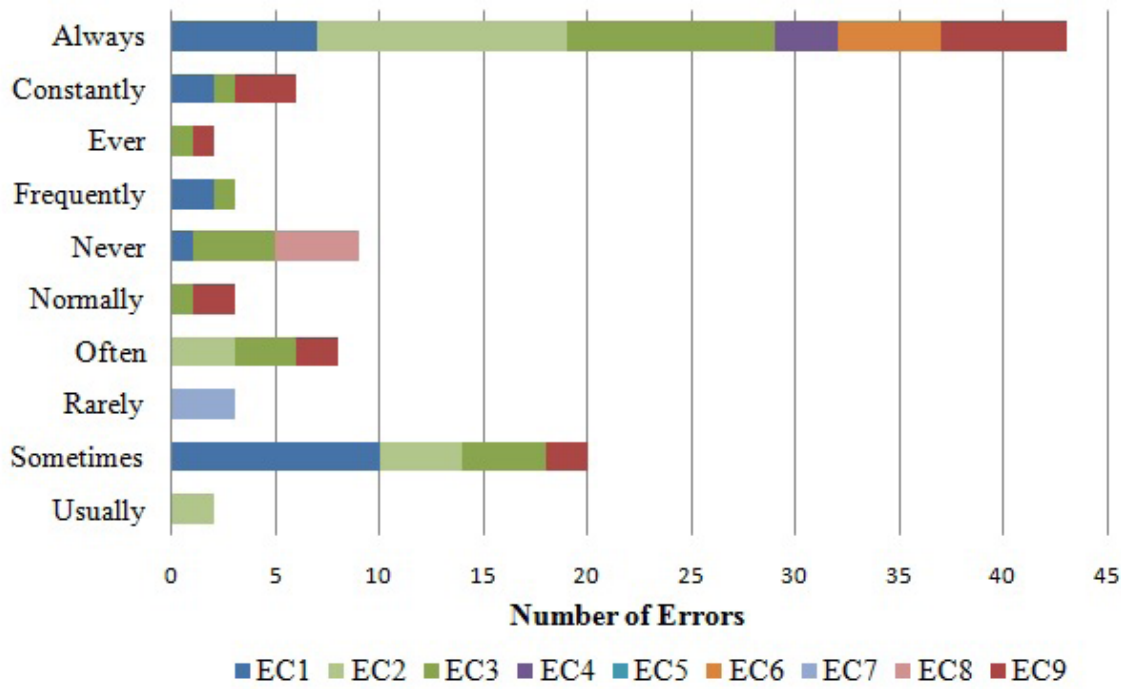

Figure 3. Overall error distribution

Ranked by the number of error types, adverbs can be divided into 5 groups: 1) always, 2) sometimes, 3) constantly, often, and never, 4) ever, normally, and frequently, and 5) usually and rarely. Hereafter, we provide a more detailed analysis of the erroneous usage of always and sometimes. In addition, we examine the adverb never as an example of the third group.

Up to six different types of erroneous use (EC1, EC2, EC3, EC4, EC6, and EC9) of the adverb always have been detected, including those

ELIA 18, 2018, pp. 15-49ＯDOI: http://dx.doi.org/10.12795/elia.2018.i18.02 
referring to its use with the verb to be, its use with simple and compound verb tenses, the use of always in initial position, and some other cases. The placement of this adverb seems equally difficult for students in both simple and compound tenses.

\begin{tabular}{|c|c|c|}
\hline Type of error & Number & Examples \\
\hline $\mathrm{EC} 1$ & 7 & $\begin{array}{l}\text {... know a perfect pronunciation, but always isn't a } \\
\text { good idea ... } \\
\text {... A tell story always be more interesting ... }\end{array}$ \\
\hline $\mathrm{EC} 2$ & 12 & $\begin{array}{l}\ldots \text { and we laugh always when this happens. } \\
\ldots \text { never forget to feed always our students with } \\
\text { cheerful and positive ... }\end{array}$ \\
\hline EC3 & 10 & $\begin{array}{l}\text { We are running out of time always, so where is the } \\
\text { need ... } \\
\ldots \text { and we always must act thinking ... }\end{array}$ \\
\hline EC4 & 3 & $\ldots$ we, as teachers, have to use it always because ... \\
\hline EC6 & 5 & $\begin{array}{l}\text { Always, I can remember this famous dialogue } \ldots \\
\text { Always worth taking the time to see ... }\end{array}$ \\
\hline EC9 & 6 & $\begin{array}{l}\text { It doesn't mind what kind of material he uses, } \\
\text { always that he knows his students ... }\end{array}$ \\
\hline
\end{tabular}

Table 5. Erroneous usage of always

Sometimes is the other adverb of frequency that is often misplaced in the sentence. As can be seen from the examples below (see Table 6), students clearly tend to place it before the verb to be, with frequent omission of the subject it. Besides, common mistakes include erroneous use of this adverb with modal verbs.

ELIA 18, 2018, pp. 15-49～DOI: http://dx.doi.org/10.12795/elia.2018.i18.02 


\begin{tabular}{|c|c|l|}
\hline Type of error & Number & \multicolumn{1}{c|}{ Examples } \\
\hline EC1 & 10 & $\begin{array}{l}\text { _. and using the internet sometimes is like playing } \\
\text { Russian roulette. } \\
\text { After the selection, sometimes is a good idea to } \\
\text { adapt the materials .. }\end{array}$ \\
\hline EC2 & 4 & $\begin{array}{l}\text { Spanish schools lack ICTs sometimes (maybe } \\
\text { because it can be expensive) ... } \\
\ldots \text { and teachers need sometimes work together and } \\
\text { those tools would be ... }\end{array}$ \\
\hline EC3 & 4 & $\begin{array}{l}\text { But sometimes can be difficult to distinguish the } \\
\text { best ... } \\
\ldots \text { playing a film or a video sometimes to our } \\
\text { students can be an excellent ... }\end{array}$ \\
\hline EC9 & 2 & $\begin{array}{l}\ldots \text { so familiar with all these things that sometimes } \\
\text { almost forget that our life ... }\end{array}$ \\
\hline
\end{tabular}

Table 6. Erroneous usage of sometimes

With regard to the use of the adverb never, major difficulties arise when using it with compound verb tenses (e.g. perfect tenses), as well as with negative verb forms (see Table 7).

\begin{tabular}{|c|c|l|}
\hline Type of error & Number & \multicolumn{1}{c|}{ Examples } \\
\hline EC1 & 1 & $\begin{array}{l}\text { I agree with you X (name of the student), never it's } \\
\text { too late to learn something. }\end{array}$ \\
\hline EC3 & 4 & $\begin{array}{l}\text { I have been never teacher ... } \\
\text {. a lot of teachers never had used them ... }\end{array}$ \\
\hline EC8 & 4 & $\begin{array}{l}\text { It won't never happen. } \\
\text {..lot of teachers who don't use never a PDI or a } \\
\text { computer ... }\end{array}$ \\
\hline
\end{tabular}

Table 7. Erroneous usage of never

As shown above, our study focused on four aspects reflecting the use of adverbs of frequency by undergraduate students: frequency of use, most

ELIA 18, 2018, pp. 15-49ＯDOI: http://dx.doi.org/10.12795/elia.2018.i18.02 
commonly misused adverbs, most common error types, and finally, adverbs with the widest range of error types.

\section{Discussion and Pedagogical Implications}

The findings of our study showed that most errors were placement-related and many of them due to the interference of the learners' first language, i.e. interlinguistic errors. In this sense, the results were not unexpected, as previous studies have concluded that "negative transfer" is one of the main sources of fossilization errors (Amara, 2015; Brown, 2001; Horwithz, 2008; Parker, 1994) and in particular "negative transfer" from Spanish to the target language.

The placement of adverbs of frequency is not generally considered to be a tricky area in the written discourse of B1 students. Besides that, asynchronous $\mathrm{CMC}$ allows students to be more precise with language use (Montero, Watts, \& Garcia-Carbonell, 2007). This raises a variety of issues. First and foremost, although it was a goal-oriented forum with a pre-established topic and, strictly speaking, the corpus is defined as "written", students focused more on social interaction with their classmates than on grammar correction. Their spontaneous use of the target language (e.g. concordance lines 3, 6, or 11 above) blurs the boundaries between written and oral communication, rendering the analysis of how the nature of written/oral discourse determines the number and nature of errors extremely difficult. Thus, we observed that the texts display characteristics of orality, such as greater spontaneity, less thorough planning, familiarity of the partners, and greater involvement, among others (Koch \& Oesterreicher, 2012), which explains the high percentage of error types related to the use of adverbs with simple tense forms or with the verb to be, something that would be unexpected in B1 undergraduate students' written work.

In spite of the complexity of the task of analyzing frequency of use and error types in asynchronous CMC, we would argue that data collected from virtual goal-oriented forums possess a great potential for the design of learning material to prevent predictable errors. According to Sauro (2009, p. 96), corrective feedback draws learners' attention to mismatches between interlanguage and its representation and target-like norm

ELIA 18, 2018, pp. 15-49～DOI: http://dx.doi.org/10.12795/elia.2018.i18.02 
facilitating the acquisition of some hard-to-learn forms. On her part, Granger recognises "the danger to exposing learners to erroneous data" but argues for the use of CLC data in contexts where "form-focused instruction" prevails, "especially in the case of fossilized language use" (2002, p. 26). Assuming that students who will take the course ICT tools applied to the learning of English languagein the following academic years will show a similar pattern of errors, we could claim that preventionoriented material mirrors corrective feedback in making learners aware of mismatches between interlanguage and target forms. In this case, instead of working with their own output, students will work with erroneous data of a representative corpus of students with the same profile. To use a learner corpus to help design teaching material, "the texts in the corpus need to be somehow related to measures of proficiency" (O'Donnell, 2013, p. 573), which in this case is B1 level, required for students who enroll in the course.

The two most commonly used types of data presentation within data-driven learning are: 1) "using raw corpus where both students and teachers will explore together" and 2) "teachers prepare teaching materials based on selected concordance lines, so they know exactly what should be discovered in the lesson, i.e., what grammar rules learners will acquire through the corpus-based data" (Phoocharoensil, 2012, p. 509). The major advantage of the second type of DDL is that it is suitable for higher education VLEs with limited time for EFL instruction, as ICT tools applied to the learning of English language does not include EFL explicit instruction.

We did not begin the study thinking in a taxonomy as a key element in the design of learning material, hence our engagement with the taxonomy as a teaching tool was post hoc. We used grammar books for the design of our error taxonomy, but at a certain point we also considered using dictionaries of errors like Turton's ABC of Common Grammatical Errors (1995); this option, however, was disregarded later on. Each entry in Turton's dictionary contains the erroneous and the right form; however, we were struck by the fact that adverbs-of-frequency-related errors were not described separately from the rest of the adverbs. For instance, he provides two examples of the rule about the use of adverbs with more than one auxiliary verb: one with always and the other with probably, a case that

ELIA 18, 2018, pp. 15-49 DOI: http://dx.doi.org/10.12795/elia.2018.i18.02 
would need clarification by a teacher, and in fully distance undergraduate courses it is crucial to provide students with self-contained material.

Given the fact that rules about adverbs of frequency do not seem to be clearly presented in a separate section in grammar books and dictionaries of errors, we consider that students will benefit from the development of an error taxonomy. To present a clear picture of the practical application of our proposal of students working with erroneous data of a representative corpus of students with the same profile, we will consider two groups. Group A includes students whose contributions to a goal-oriented online forum have been previously analysed (e.g. see Table 1) and group B includes students enrolled in the same degrees in the Expert in English Language Teaching program in subsequent academic years. We take group A and group B to have similar profiles and assume that group B will make similar mistakes to those detected in the analysis of the contributions of group A.

The prevention-oriented activities designed for group B will take place at the beginning of the course and will consist of two steps: 1) students design an error taxonomy and 2) students analyse adverb-of-frequencyrelated errors in selected concordance lines from corpus collected from group A students' posts. The first step aims at integrating grammar instruction into students' critical analysis of their own written discourse. The second step aims at increasing their self-awareness and self-regulation as part of the learning process. Providing students with the researcher/ teacher perspective will help them gain autonomy, improve their analytic skills, and encourage them to see the importance of grammar correctness in their own writing. These data-driven activities will not only reduce the occurrence of the predicted errors, but will also improve students' "problem-solving, critical analysis and independent learning capabilities" (Cheng, 2012, p. 9).

One limitation to be taken into consideration is that the teacher who will design the prevention-oriented activities for group B should have access to the learner corpus of group A. Alternatively, the teacher or material developer can have access not to the corpus itself, but to the results of the corpus-based analysis of group A and to those concordance lines that include adverb-related errors.

ELIA 18, 2018, pp. 15-49～DOI: http://dx.doi.org/10.12795/elia.2018.118.02 


\section{Conclusions}

The results obtained in this study show that the most common types of error involve wrong placement of the adverbs of frequency. This should not be surprising, since adverbs are considered the most movable element in English (Carter, Hughes, \& McCarthy, 2000). The value of corpus data gathered from online discussion forums is twofold: it raises researchers' and teachers' awareness of the blending of written and oral communication in VLEs, and findings help design materials to prevent problematic usage, often neglected in general grammar books. It also proves that online forms of interaction, such as virtual forums, require a profound rethinking of the traditional distinction between oral and written discourse, hence the distinction between oral and written corpora.

We share Seidlhofer's criticism of materials designed for the "archetypal learner" and her claim that "an appropriate pedagogy needs to be fine-tuned to specific learners" (2002, p. 214). To illustrate the potential of data collected from asynchronous $\mathrm{CMC}$, such as virtual forums, we proposed a two-step model for prevention-oriented material, which includes the development of error taxonomy and the analysis of errors in selected concordance lines. This model opens a wide range of possibilities for teachers to promote more active, learner-centered approach, increasing students' motivation and autonomy and can be readily adapted to a wide variety of higher education learning contexts.

\section{Acknowledgements}

This study is part of the research project "Detección y análisis del comportamiento lingüístico de producciones escritas de estudiantes universitarios", (Ref: B0036-1617-104-ETEL. Universidad Internacional de La Rioja, 2016-2017). We would like to thank Dr. Cristina Castillo Rodríguez, main researcher of the research group ENTELEARN (English, Technologies, and Learning), for her support and careful reading of an earlier version of this article. We would also like to thank the anonymous reviewers for their helpful suggestions and comments. 


\section{References}

Ackerley, K. (2013). A comparison of learner and native speaker writing in online self-presentations: pedagogical applications. In S. Granger, G. Gilquin, \& F. Meunier (Eds.), Twenty years of learner corpus research. Proceedings of the first learner corpus research conference (pp. 1-10). Louvain-la-Neuve: Presses Universitaires de Louvain.

Ädel, A. (2015).Variability in learner corpora. In S. Granger,G. Gilquin, \& F. Meunier (Eds.), Cambridge handbook of learner corpus research (pp.379400). Cambridge, UK: Cambridge University Press.

Alejo González, R. (2010). L2 Spanish acquisition of English phrasal verbs. In M.C. Campoy (Ed.), Corpus-based approaches to English language teaching(pp. 149-166). London/New York: Continuum.

Alonso Alonso, R. (1997). Language transfer: Interlingual errors in Spanish students of English as a foreign language. Revista Alicantina de Estudios Ingleses 10, 7-1.

Amara, N. (2015). Errors correction in foreign language teaching. The Online Journal of New Horizons in Education, 5(3), 58-68.

Barton, G. (1999). Grammar in Context. Oxford: OUP.

Belz, J., \& Vyatkina, N. (2005). Learner corpus analysis and the development of L2 pragmatic competence in networked intercultural language study: the case of German modal particles. The Canadian Modern Language Review, 62(1), 17-48. https://doi.org/10.3138/cmlr.62.1.17

Bernardini, S. (2004). Corpora in the classroom: An overview and some reflections on future developments. In J. McH. Sinclair (Ed.), How to use corpora in language teaching (pp.15-36). Amsterdam: John Benjamins.

Biber, D., \& Conrad, S. (2004). Corpus-based comparisons of register. In C. Coffin, A. Hewings, \& K. O'Halloran (Eds.), Applying English grammar (pp. 40-56). London: Arnold/The Open University.

Bongaerts, T. (1999). Ultimate attainment in L2 pronunciation: The case of very advanced late L2 learners. In D. Birdsong (Ed.), Second language acquisition and the critical period hypothesis (pp. 133-159). Mawah, NJ: Lawrence Erlbaum Associates.

ELIA 18, 2018, pp. 15-49ＯDOI: http://dx.doi.org/10.12795/elia.2018.118.02 
Brown, H. (2001). Teaching by principles: An interactive approach to language pedagogy. White Plains, NY: Longman.

Callies, M. (2015). Using learner corpora in language testing and assessment: Current practice and future challenges. In E. K. Castello, K. Ackerley, \& F. Coccetta (Eds.), Studies in learner corpus linguistics: Research and applications for foreign language teaching and assessment (pp. 21-35). Frankfurt, Germany: Peter Lang. https//doi:10.3726/978-3-0351-0736-4

Carter, R., Hughes, R., \& McCarthy, M. (2000). Exploring grammar in context. Cambridge: Cambridge University Press.

Castillejos López, W. (2009). Error analysis in a learner corpus. What are the learners' strategies? In AELINCO (Ed.), Actas del I Congreso Internacional de Lingüistica de Corpus (CILC'09) (pp. 675-690). Paper presented at I Congreso Internacional de Lingüística de Corpus, Universidad de Murcia (Spain). Murcia: AELINCO.

Castillo Rodríguez, C., \& Díaz Lage, J. (2015). Exploitation of a learner corpus: Analysing openings and endings in academic forums. Opción, 31(6), 192210.

Celce-Murcia. M. (1991). Grammar pedagogy in second and foreign language teaching. TESOL Quarterly, 25(3), 459-480. https://doi. org/10.2307/3586980

Celce-Murcia, M., \& Larsen-Freeman, D. (1999). The Grammar book: An ESL/ EFL teacher's course (2nd ed.). Boston, MA: Heinle and Heinle.

Chambers, A. (2005). Integrating corpus consultation in language studies. Language Learning and Technology, 9(2), 111-125.

Chalker, S., \& Weiner, E. (1998). The Oxford Dictionary of English Grammar. Oxford: Oxford University Press.

Cheng, W. (2012). Exploring corpus linguistics. Language in action. London and New York: Routledge.

Coe, N. (1987). Speakers of Spanish and Catalan. In M. Swan \& B. Smith (Eds.), Learner English: A Teacher's guide to interference and other problems (pp. 90-112). Cambridge: Cambridge University Press.

ELIA 18, 2018, pp. 15-49ＯDOI: http://dx.doi.org/10.12795/elia.2018.i18.02 
Conrad, S. (2000). Will corpus linguistics revolutionize grammar teaching in the $21^{\text {st }}$ century? TESOL Quarterly, 34, 548-560. https://doi. org $/ 10.2307 / 3587743$

Cambridge Dictionary Online. Retrieved from https://dictionary.cambridge.org/es

Council of Europe. (2001). Common European Framework of References for Languages: learning, teaching, assessment. Cambridge: Cambridge University Press.

Cowan, R. (2008). The teacher's grammar of English. Cambridge: Cambridge University Press.

Crandall, J.A., Dias, J., Gingras, R.C., \& Harris, T.K. (1981). Teaching the Spanishspeaking child. Englewood Cliffs, NJ: Prentice Hall Regents.

Crystal, D. (1995). The Cambridge Encyclopedia of the English Language. Cambridge: Cambridge University Press.

DeJonge, S., \& Kemp, N. (2012). Text-message abbreviations and language skills in high school and university students. Journal of Research in Reading, 35(1), 49-68.

DeKeyser, R. (2007). Practice in a second language: Perspectives from applied linguistics and cognitive psychology. Cambridge: Cambridge University Press

Díez-Bedmar, M. B. (2009). Written learner corpora by Spanish students of English: An overview. In P. C. Gómez \& A. S. Pérez (Eds.), A Survey of corpus-based research (pp. 920-33). Murcia: Asociación Española de Lingüística del Corpus.

Dooly, M., \& O'Dowd, R. (2012). Researching online interaction and exchange in foreign language education. In M. Dooly, \& R. O'Dowd (Eds.), Researching online foreign language interaction and change: Theories, methods and challenges (pp. 11-44). Bern: Peter Lang.

Dotti, F., \& O'Donnell, M. (2014, September). Addressing article errors in Spanish Learners of English using a learner corpus. Paper presented at the 2014 TSLL Conference, Iowa State University.

ELIA 18, 2018, pp. 15-49ＯDOI: http://dx.doi.org/10.12795/elia.2018.118.02 
Dulay, H. C., Burt, M. K., \& Krashen, S. (1982). Language two. New York: Oxford University Press.

Ellis, R. (1993). The study of second language acquisition. Oxford: Oxford University Press.

Ellis, R. (2006). Current issues in the teaching of grammar: An SLA perspective. TESOL Quarterly, 40(1), 83-107. https://doi.org/10.2307/40264512

Ellis, R., Basturkmen, H., \& Loewen, S.(2002). Doing focus-on-form. System, 30(4), 419-432. https://doi.org/10.1016/S0346-251X(02)00047-7

Gablasova, D., Brezina, V., \& McEnery, T. (2017). Exploring learner language through corpora: Comparing and interpreting corpus frequency information. Language Learning, 67, 130-154. https://doi:10.1111/lang.1222

Gardner, D., \& Davie, M. (2007). Pointingout frequent phrasal verbs: A corpusbased analysis. TESOL Quarterly, 41(2), 339-359. https://doi. org/10.1002/j.1545-7249.2007.tb00062.x

Garner, J. (2013). The use of linking adverbials in academic essays by non-native writers: How Data-driven learning can help. Calico Journal, 30(3), 410422. https://doi.org/10.11139/cj.30.3.410-422

Gaskell, D., \& Cobb, T. (2004). Can learners use concordance feedback for writing errors? System,32, 301-319. https://doi.org/10.1016/j.system.2004.04.001

Granger, S. (2002). A bird's eye view of learner corpus research. In S. Granger, J. Hung \& S. Petch-Tyson (Eds.), Computer learner lorpora, second language acquisition and foreign language teaching (pp. 3-33). Amsterdam: John Benjamins.

Granger, S. (2012). How to use foreign and second language learner corpora. In A. Mackey \& S.M. Gass (Eds.), Research methods in second language acquisition: A practical guide (pp.7-29). Oxford, UK: Wiley-Blackwell.

Granger, S., Gilquin, G., \& Meunier, F. (2015). Introduction: Learner corpus research - past, present and future. In S. Granger, G. Gilquin, \& F. Meunier (Eds.), The Cambridge Handbook of Learner Corpus Research (Cambridge Handbooks in Language and Linguistics, pp. 1-6). Cambridge: Cambridge University Press.

ELIA 18, 2018, pp. 15-49

DOI: http://dx.doi.org/10.12795/elia.2018.i18.02 
Gray, B. E. (2005). Error-specific concordancing for intermediate ESL/EFL writers. Retrieved January 18, 2016 from http:// dana.ucc.na4.edu/ bde6/ coursework/Projects/PedagogicalTip/homepage.html.

Green, J. C. (2007). Mixed methods in social inquiry. San Francisco: Jossey-Bass.

Gries, S. (2015). Statistical methods in learner corpus research. In Gaëtanelle Gilquin, Sylviane Granger, \& Fanny Meunier (Eds.), The Cambridge handbook oflearner corpus research (pp.159-181). Cambridge: Cambridge University Press.

Han, Z.H. (2004). Fossilization in adult second language acquisition. Clevedon: Multilingual Matters.

Harvey, K. (2012). Disclosures of depression: using corpus linguistics methods to interrogate young people's online health concerns. International Journal of Corpus Linguistics, 17(3), 349-379. https://doi.org/10.1075/ijcl.17.3.03har

Hewings, A., \& Hewings, M. (2005). Grammar and context: An advanced resource book. London \& New York: Routledge.

Hewings, M. (2005). Advanced grammar in use. Cambridge: Cambridge University Press.

Horwithz, E. (2008.). Becoming a language teacher.Boston: Pearson.

Ioup, G. B. (1994). Reexamining the critical period hypothesis. Studies in Second Language Acquisition,16, 73-98. https://doi.org/10.1017/ S0272263100012596

Jichun, P. (2015). A Corpus-based study on errors in writing committed by Chinese students. Linguistics and Literature Studies, 3(5), 254-258.https://doi. org/10.13189/1ls.2015.030509

Koch, P.,\& Oesterreicher, W. (2012). Language of immediacy - language of distance: orality and literacy from the perspective of language theory and linguistic history. In C. Lange, B. Weber \& G. Wolf (Eds.), Communicative Spaces, Variation, Contact, and Change - Papers in Honour of Ursula Schaefer (pp. 441-473). Bern: Peter Lang.

Kress, G. (2003). Literacy in the new media age. London: Routledge.

ELIA 18, 2018, pp. 15-49ＯDOI: http://dx.doi.org/10.12795/elia.2018.i18.02 
Leech, G. (2011).Frequency, corpora and language learning. In F. Meunier,S. De Cock, \& G. Gilquin (Eds.), A taste for corpora. In honour of Sylviane Granger (pp.7-31). Amsterdam: John Benjamins.

Leech, G., Rayson, P., \& Wilson, A. (2001). Word frequencies in written and spoken English: Based on the British National Corpus. London: Longman.

Lei, L. (2012). Linking adverbials in academic writing on applied linguistics by Chinese doctoral students. Journal of English for Academic Purposes, 11(3), 267-275. https://doi.org/10.1016/j.jeap.2012.05.003

Leiva de Izquierdo, B., \& Esteves Reyes, L. (2009). Effectiveness of blogging to practice reading at a freshman EFL program. The Reading Matrix, 9(2), $100-117$.

Liang, M. (2010). Using synchronous online peer response groups in EFL writing: Revision-related discourse. Language Learning and Technology, 14(1), 4564.

Liaw, M. L., \& Master, S. B. (2010). Understanding telecollaboration through an analysis of intercultural discourse. Computer Assisted Language Learning,23(1), 21-40. https://doi.org/10.1080/09588220903467301

Lin, Y. L. (2013). Discourse functions of recurrent multi-word sequences in online and face-to-face intercultural communication. In J. Romero-Trillo (Ed.), Yearbook of corpus linguistics and pragmatics (pp. 105-129). London: Springer.

Lin, Y. (2015). Contrastive analysis of adolescent learner interlanguage in asynchronous online communication: A keyness approach. System, 55, 5362. https://doi.org/10.1016/j.system.2015.08.011

Lozano, C., \& Mendikoetxea, A. (2013). Learner corpora and second language acquisition: the design and collection of CEDEL2. In A. Díaz-Negrillo, N. Ballier\& P. Thompson (Eds.), Automatic treatment and analysis of learner corpus data (pp. 65-100). Amsterdam: John Benjamins.

Lyddy, F., Farina, F.; Hanney, J., Farrell, L.,\& O’Neill N. (2014). An analysis of language in university students text messages, Journal of ComputerMediated Communication, 19(3), 546-561. https://doi.org/10.1111/ jec4.12045

ELIA 18, 2018, pp. 15-49ＯDOI: http://dx.doi.org/10.12795/elia.2018.i18.02 
MacWhinney, B. (2000). The CHILDES project: Tools for analysing language. Mahwah NJ: Lawrence Erlbaum Associates.

Martinec, R., \& van Leeuwen, T. (2008). The language of new media design: Theory and Practice. London: Routledge.

Mendikoetxea, A., Murcia Bielsa, S., \& Rollinson, P. (2010). Focus on errors: Learner corpora as pedagogical tools. In M. C. Campoy-Cubillo, B. Bellés Fortuño, \& M. L. Gea-Valor (Eds.), Corpus-based approaches to English language teaching (pp. 181-194). London/New York: Continuum.

Meunier, F. (2007). The pedagogical value of native and learner corpora in EFL grammar teaching. In W. Teubert \& R. Krishnamurthy (Eds.), Corpuslinguistics: Critical concepts in linguistics (pp. 119-141), London \& New York: Routledge.

Meunier, F. (2010). Learner corpora and English Language Teaching: Checkuptime. Anglistik: International Journal of English Studies, 21(1), 209-220.

Montero, B., Watts, F., \& Garcia-Carbonell, A. (2007). Discussion forum interactions: text and context. System, 35, 566-582. https://doi.org/10.1016/j. system.2007.04.002

Neff, J., Martinez, F. \& Rica, J. P. (2001). A contrastive study of qualification devices in native and non native argumentative texts in English. Paper presented at the annual meeting of the American Association of Applied Linguistics, February, 2001: St. Louis, MO.

Nikolov, M. (2009). The age factor in context. In M. Nikolov (Ed.), The age factor and early language learning (pp. 1-39). Berlin: Mouton de Gruyter.

O’Donnell, M. (2012). Using learner corpora to redesign university-level EFL Grammar education. Revista Española de Lingüística Aplicada(RESLA),1, 145-160.

O’Donnell, M. (2013). From learner corpora to curriculum design: An empirical approach to staging the teaching of grammatical concepts. Procedia Social and Behavioral Sciences, 95, 571-580.

Odlin, T. (2001). Language transfer, cross-linguistic influence in language learning. Shanghai: Shanghai Foreign Language Education Press.

ELIA 18, 2018, pp. 15-49～DOI: http://dx.doi.org/10.12795/elia.2018.i18.02 
Parker, F. (1994). Linguistics for non-linguists. Needham Heights, MA: Allyn \& Bacon.

Parrot, M. (2000). Grammar for English language teachers. Cambridge: Cambridge University Press.

Pérez Sánchez, A. M. (2013). A corpus-based analysis of errors in adult EFL writings. Revista Nebrija de Lingüistica Aplicada, 13. Retrieved from https://www.nebrija. com/revista-linguistica/a-corpus-based-analysis-of-errors-in-adult-efl-writings. $\mathrm{html}$

Philip, G. (2008, July). Adverb use in EFL student writing: from learner dictionary to text production. Paper presented in the Proceedings of the XIII EURALEX International Congress, Barcelona, 15-19 July (pp. 1301-1310).

Phoocharoensil, S. (2012). Language corpora for EFL teachers: An exploration of English grammar through concordance lines. Procedia - Social and BehavioralSciences, 64, 507-514.

Raimes, A. (2001). Grammar troublespots: An editing guide for students. Cambridge: Cambridge University Press.

Rakhilina, E., Vyrenkova, A., Mustakimova, E., Ladygina, A., \& Smirnov, I. (2016). Building a learner corpus for Russian. Proceedings of the joint workshop on NLP for Computer Assisted Language Learning and NLP for Language Acquisition at SLTC 2016. Linköping Electronic Conference Proceedings, 130, 66-75.

Rutherford, W. (1987). The meaning of grammatical consciousness-raising. Word Englishes,6, 209-216. https://doi.org/10.1111/j.1467-971X.1987. tb00201.x

Sasaki, A. (2010). EFL students' vocabulary learning in NS-NNS e-mail interactions: Do they learn new words by imitation? ReCALL,22(1),70-82. https://doi.org/10.1017/S0958344009990206

Sauro, S. (2009). Computer-mediated corrective feedback and the development of L2 grammar. Language Learning and Technology, 13(1), 96-120.

Schmidt, R. (2001). Attention. In P. Robinson (Ed.), Cognition and second language instruction (pp. 3-32). Cambridge: Cambridge University Press.

ELIA 18, 2018, pp. 15-49ＯDOI: http://dx.doi.org/10.12795/elia.2018.i18.02 
Seidlhofer, B. (2002). Pedagogy and local learner corpora: working with learning driven data. In S. Granger, J. Hung \& S. Petch-Tyson (Eds.), Computer learner corpora, second language acquisition and foreign language teaching (pp. 213-234). Amsterdam: John Benjamins.

Selinker, L. (1972). Interlanguage. International Review of Applied Linguistics, 10, 209-241. https://doi.org/10.1515/iral.1972.10.1-4.209

Selinker, L. (1992). Rediscovering interlanguage. London: Longman.

Shichun, G. (2004). A cognitive model of corpus-based analysis of Chinese learners' errors of English. Modern Foreign Languages, 27, 129-139.

Solís Hernández, M. (2006). The position of adverbs in English: Trying to solve a major problem most language learners usually face. Filología y Lingüistica $32(1), 271-285$.

Stefanova, S., Bobkina, J. (2015). A Corpus-based study of adverbs of frequency in EFL students'writing: A case of distance learning. In IATED (Ed.), Proceedings. Paper presented at 7th International Conference on Education and New Learning Technologies (EDULEARN15), Barcelona (Spain). Barcelona: IATED.

Sindoni, M. (2013). Spoken and written discourse in online interactions: A multimodal approach. New York: Routledge.

Thomson, A. J., \& Martinet, A.V. (1986). A Practical English Grammar. Oxford: Oxford University Press.

Torrado-Cespón, M., \& Díaz-Lage, J. M. (2017). Error analysis and interlanguage in the use of the term 'ICT' in an online learner corpus, Complutense Journal of English Studies, 25, 105-123. https://doi.org/10.5209/ CJES.56354

Turton, N.D. (1995). ABC of common grammatical errors. Oxford: Macmillan Heinemann English Language Teaching.

Tyler, A. (2012). Cognitive linguistics and second language learning: Theoretical basics and experimental evidence. New York, NY: Routledge

Varley, S. (2008). I'll just look that up in the concordance: Integrating corpus consultation into the language learning environment. Computer Assisted Language Learning, 22(2), 133-152. https://doi.org/10.1080/09588220902778294

ELIA 18, 2018, pp. 15-49～DOI: http://dx.doi.org/10.12795/elia.2018.i18.02 
Varnhagen, C., McFall, P., Pugh, N., Routledge, L., Sumida-MacDonald, H., \& Kwong, T. E. (2010). New language and spelling in instant messaging. Reading and Writing, 23(6), 719-733. https://doi.org/10.1007/s11145-0099181-y

Wei, X. (2008). Implication of IL fossilization in second language acquisition. English Language Teaching, 1(1), 127-131. https://doi.org/10.5539/elt. v1n1p127

Yilmaz, E., \& Dikilitaş, K. (2017). EFL learners' uses of adverbs in argumentative essays. Research on Youth and Language, 11(1), 69-87.

First version received: July, 2018

Final version accepted: October, 2018

ELIA 18, 2018, pp. 15-49ＯDOI: http://dx.doi.org/10.12795/elia.2018.i18.02 